\title{
Prevalence of Hepatitis B Virus and Hepatitis C Virus Infections among Beauticians in Quy Nhon City, Binh Dinh Province, Vietnam
}

\section{Tinh Huu Ho ${ }^{1,2}$, Chaweewon Boonshuyar', Uraiwan Kositanont', Chinh Van Dang ${ }^{2}$, Ai Ha Phan Nguyen ${ }^{2}$, Vinh Ouang Nguyen ${ }^{2}$, Nguyen Phuong Toai ${ }^{3}$, Pirom Noisumdaeng'}

${ }^{1}$ Faculty of Public Health, Thammasat University (Rangsit Center), Khlong Luang, Pathum Thani, 12121, Thailand. ${ }^{2}$ Institute of Public Health, Ministry of Health, 159 Hung Phu Street, Ward 8, District 8, Ho Chi Minh City-700000, Vietnam.

${ }^{3}$ Department of Research and International Relations, Can Tho Medical College, 340 Nguyen van Cu Street, Can Tho City, Vietnam.

DOI: https://doi.org/10.24321/2319.9113.201806

Abstract
Objective: To determine the prevalence of hepatitis B virus (HBV) and hepatitis C virus (HCV) infections
among beauticians and to identify occupational risk factors associated with the infections.
Methods: The cross-sectional study of 247 randomly enrolled beauticians was conducted in Quy Nhon City,
Viet Nam. Knowledge, perceptions, and practices towards occupational risk of HBV and HCV infections
were evaluated using an anonymous questionnaire. Blood samples were tested for hepatitis B surface
antigen (HBsAg) and antibodies against HBV and HCV by chemiluminescent microparticle immunoassay.
Viral genotyping by real time quantitative PCR was performed for those testing positives for HBsAg and
anti-HCV antibodies.
Results: The prevalence of HBV and HCV infections was $7.3 \%$ (18/247, $95 \%$ Cl: $4.4-11.3$ ) and 0\%, respectively.
Among HBsAg(+) subjects, $72.2 \%$ (13/18) were identified as being infected with HBV genotype B. Overall,
198/247 (80.2\%) perceived that they are at risk of being infected by hepatitis through work. Nearly half of
participants (43.3\%) were not immune to HBV.
Discussions: The prevalence of HBV and HCV infections among beauticians was comparable to the general
population previously of Vietnam; no occupational risk factors associated with infections were found. This
finding proposed that beauticians might not be a high-risk group for HBV and HCV infections. However, the
study revealed a high proportion of persons susceptible to HBV infections suggesting that public health
preventive strategies and vaccination targeting these professionals should be implemented.
Keywords: Beauty treatment occupation, Beauticians, Viral hepatitis, HBV infection, HCV infection

\section{Introduction}

Infections with hepatitis B virus (HBV) and hepatitis $C$ virus (HCV) are globally significant public health issues. In 2015, it was estimated that 257 million and 71 million people were chronically infected with $\mathrm{HBV}$ and $\mathrm{HCV}$, respectively. ${ }^{1} \mathrm{HBV}$ prevalence worldwide in 2015 was 3.5\% (95\% Cl: 2.7-5.0), with the highest prevalence reported in the Western Pacific

Corresponding Author: Tinh Huu Ho, Thammasat University (Rangsit Center), Khlong Luang, Pathum Thani, 12121, Thailand \& The Institute of Public Health, Ministry of Health, 159 Hung Phu Street, Ward 8, District 8, Ho Chi Minh City-700000, Vietnam.

E-mail Id: hohuutinhytcc@gmail.com

Orcid Id: https://orcid.org/0000-0002-0706-8978

How to cite this article: Ho TH, Boonshuyar C, Kositanont U et al. Prevalence of Hepatitis B Virus and Hepatitis C Virus Infections among Beauticians in Quy Nhon City, Binh Dinh Province, Vietnam. J Integ Comm Health 2018; 7(1): 31-41. 
Region (6.2\%, 95\% Cl: 5.1-7.6) and Africa (6.1\%, 95\% Cl: 4.6-8.5). ${ }^{1}$ Meanwhile, the global prevalence of $\mathrm{HCV}$ infection was $1.0 \%$ (95\% Cl: 0.8-1.1), and the predominant areas included the Eastern Mediterranean Region (2.3\%, 95\% $\mathrm{Cl}$ : 1.9-2.4) and the European Region (1.5\%, 95\% Cl: $1.2-$ 1.5). ${ }^{1} \mathrm{HBV}$ and HCV are transmitted by several pathways, such as sexual intercourse, injection drug use, receipt of infected blood products, mother to newborn transmission, and occupational exposures. ${ }^{2}$ Occupational transmission occurs from accidental injury enabling exposure to infected blood or body fluids. These injuries occur from contact with contaminated sharp instruments (such as razors, needles, or scissors) in healthcare and non-healthcare settings. ${ }^{2}$

Cosmetology is a rapidly growing field, resulting in increasing numbers of beauty salons and beauticians. ${ }^{3}$ Previous reports have suggested that beauty treatments, such as cosmetic tattooing, ${ }^{4}$ manicuring and pedicuring, haircutting, and shaving might pose a risk for the transmission of bloodborne viruses, particularly HBV and HCV. ${ }^{5,6}$ Beauticians may be accidentally exposed to clients' blood or body fluids while providing treatments. Additionally, reusing razors or sharing inadequately sterilized equipment is a risk factor for blood-borne virus transmission. ${ }^{5,7} \mathrm{HBV}$ specifically has been detected on used razors and nail scissors. ${ }^{5,8}$ However, some studies reported that the prevalence of viral hepatitis infection among beauticians was similar to the general population, ${ }^{12-14}$ and were not able to link being a beautician to an increased risk of acquiring viral hepatitis. ${ }^{9-11}$

In Vietnam, several studies reported that the HBV prevalence in the general population based on positive hepatitis $B$ surface antigen ( $\mathrm{HBsAg}$ ) ranges from $8.8 \%$ to $20.5 \%,{ }^{12-16}$ indicating a considerable problem for the health system. Meanwhile, the HCV prevalence based on positive antibody against HCV (anti-HCV) among the general population ranges from $0.35 \%$ to $2.2 \%{ }^{17-19}$ The most common route of HBV transmission reported in Vietnam is mother to child transmission, ${ }^{20}$ whereas unsafe injection is the main transmission mode for HCV. ${ }^{21}$ However, no study has been conducted on the relationship between providing beauty treatments and viral hepatitis infection. Therefore, the objectives of this study were to determine the prevalence of HBV and HCV infections among beauticians in a crosssectional study and evaluate beautician's knowledge, perceptions, and practices of preventing hepatitis virus infections.

\section{Methods}

\section{Study design and participants}

A cross-sectional study was carried out from August to November 2017 among beauticians in Quy Nhon City, Binh Dinh Province, Vietnam. The study area was selected because of its high density population and rapidly growing demand for beauty treatment services. Participants were selected based on a list of names of beauticians provided by local health workers. Local health workers visited each beauty salon to clearly explain the study and developed the list of beauticians who agreed to join. The sample size was calculated using a formula for estimating a finite population proportion. ${ }^{22}$ Based on a total of 336 beauticians, an anticipated prevalence of HBV among the general population of $15.3 \%,{ }^{13}$ a confidence level of $95 \%$, and absolute precision of $2.5 \%$, the sample size was calculated as 237 . In order to overcome potential quality control lapses during processing and storing blood samples and missing questionnaire data, 247 participants (73.5\% of the total number of beauticians in Quy Nhon) were ultimately recruited.

The participants were beauticians who directly provided personal beauty care treatment services for their clients, including hair cutting and styling, shaving, tattooing, manicuring, and pedicuring. The inclusion criteria were any beautician in Quy Nhon who: 1) was at least 18 years old 2) had worked as a beautician for a minimum of 6 months and 3) agreeed to be interviewed and give a blood sample. The discontinuation criteria included incomplete interviewing or inadequate blood sample.

\section{Data collection}

Eligible beauticians were invited to The Preventive Medicine Center (PMC) in Quy Nhon City for interviews and laboratory examinations for HBV and HCV. Information on sociodemographic factors, knowledge, perceptions and practices was collected anonymously by trained medical staff through an in-person, structured questionnaire. A $5 \mathrm{ml}$ blood sample was drawn from each participant and collected into gel vacuum tubes by the standard method under aseptic conditions. Serum samples were obtained by centrifugation, kept in polystyrene tubes, and stored at $-20^{\circ} \mathrm{C}$ until used. Participants who were positive for $\mathrm{HBsAg}$ or anti-HCV had an additional $3 \mathrm{ml}$ of venous blood drawn at a second visit for viral genotyping.

\section{Questionnaire}

The questionnaire was designed in four parts: (i) participant characteristics, (ii) knowledge, (iii) perception, and (iv) practice of hepatitis virus prevention. The participant characteristics included gender, age, marital status, education, work experience, monthly income, type of occupation (including haircutting, shaving, manicuring, pedicuring, tattooing, hair washing, spot squeezing, ear cleaning), average number of customers served per day, and history of a blood transfusion or tattoo. The knowledge section had 16 questions covering four dimensions that included mode of transmission, vaccination and treatment, prevention activities, and symptoms. Participants were also interviewed on their perception of occupational risk of HBV and HCV infections through one main question and four sub-questions. Regarding practice, a series of 20 questions were used to collect information on the 
history of occupational injuries, washing hands, wearing gloves, reusing razors or blades, frequency and method of washing towels, and frequency and methods of cleaning instruments. Cronbach's alpha was used to test the internal consistency of questionnaire items, resulting in coefficients of 0.78 for knowledge, 0.80 for perception, and 0.70 for practice. The external validity of the questionnaire was evaluated by consulting three experts.

\section{Serological testing}

The status of HBV and HCV infections were determined through the detection of hepatitis biomarkers: HBsAg, antibody to hepatitis B surface antigen (anti-HBs), antibody to hepatitis B core antigen total (anti-HBc total including immunoglobulin M (IgM) and Immunoglobulin G (IgG)), and anti-HCV by using the chemiluminescent microparticle immunoassay technique (CMIA). Abbott reagent kits were used for biomarker detection, including Architect HBsAg Qualitative II, Architect Anti-HBs, Architect Anti$\mathrm{HBC}$ II, Architect Core-M and Architect Anti-HCV (Abbott, Wiesbaden, Germany). Viral genotype was determined for participants who were $\mathrm{HBsAg}(+)$ or anti-HCV(+) by quantitative real-time polymerase chain reaction (PCR) with Taqman ${ }^{\circ}$ probes. The serological test and genotyping was done at the Medic Medical Central laboratory, Ho Chi Minh city.

\section{Data analysis}

The knowledge and practice sections of the questionnaire were summarized by score and then classified into three levels including high (above $80 \%$ right answers), moderate (60\%-80\% right answers) and low (under 60\% right answers). Participants were stratified by the detection of $\mathrm{HBsAg}(+)$ or anti-HCV (+) for further statistical calulation. Data analysis was carried out according to a pre-established analysis plan using Epidata 3.1 for entry and STATA version 14.0 for analysis. Proportions were compared using Chi-squared tests with continuity correction or Fisher's exact test when appropriate. Multivariable analyses were conducted with binary logistic regression. An association was considered statisically significant when the $p$-value was lower than $5 \%$ and the $95 \%$ confidence interval $(\mathrm{Cl})$ of the odds ratio (OR) did not include 1.0.

\section{Results}

\section{Characteristics of participants}

Among the 247 participants enrolled in the study, females accounted for 200/247 (81.0\%). Ages ranged from 18-67 years old with $133 / 247$ (53.9\%) being $18-30$ years old. Most participants completed secondary school 111/247 (44.9\%) or higher $116 / 247$ (47.0\%). Overall, 146/247 (59.1\%) of participants were married and $7 / 247$ (2.8\%) were divorced. Monthly incomes ranged from 50 to 1000 United States dollars (USD) (median: 150 USD). Regarding length of work experience, $114 / 247$ (46.2\%) of participants had worked less than 5 years, while 92/247 (37.2\%) had worked for more than 10 years; $134 / 247$ (54.3\%) of participants had five to nine customers daily and $32 / 247(13.0 \%)$ had less than five customers daily. The details of participant characteristics are presented in Table S1.

\section{Prevalence of $\mathrm{HBV}$ and $\mathrm{HCV}$ infections in beauticians}

Of all of the participants, $18 / 247$ (7.3\%, 95\% Cl: 4.4-11.3) were found to be infected with HBV by $\mathrm{HBsAg}(+)$; no participants tested positive for HCV (Table 1). HBV with genotype B was found in 13/18 (72.2\%) of participants infected with HBV, while HBV genotype was unidentified $27.8 \%$ (5/18). On serologic testing, 107/247 (43.3\%) had no evidence of immunity to HBV. Some 32/247 (13.0\%) had evidence of immunity through vaccination and $81 / 247$ (32.8\%) had evidence of immunity through resolved natural infection. No participant had acute infection; however, $3.6 \%$ (9/247) had evidence of had recent resolving HBV infections. All 18 participants with circulating HBV antigen were in the chronic phase of infection (Table 1).

Table 1. Prevalence of hepatitis $B$ virus and hepatitis $\mathrm{C}$ virus (HBV/HCV) infections among 247 beauticians in Quy Nhon City, Binh Dinh Province, Viet Nam, 2017

\begin{tabular}{|c|c|c|c|c|}
\hline \multirow[t]{2}{*}{ Prevalence of HBV/HCV infections } & \multirow[t]{2}{*}{ Number } & \multirow[t]{2}{*}{ Percent } & \multicolumn{2}{|c|}{$95 \% \mathrm{Cl}$} \\
\hline & & & Lower & Upper \\
\hline \multicolumn{5}{|l|}{ Hepatitis serologic tests of HBV } \\
\hline $\mathrm{HBsAg}(+)$ & 18 & 7.3 & 4.4 & 11.3 \\
\hline Anti-HBc-IgM(+) among $18 \mathrm{HBsAg}(+)$ & 0 & 0.0 & & \\
\hline Anti-HBs(+) & 113 & 45.6 & 39.4 & 52.2 \\
\hline Anti-HBc(+) & 108 & 43.7 & 37.4 & 50.2 \\
\hline \multicolumn{5}{|l|}{ Genotype of HBV among $18 \mathrm{HBsAg}(+)$} \\
\hline Genotype B & 13 & 72.2 & 46.5 & 90.3 \\
\hline Lower limit of detection* & 5 & 27.8 & 9.7 & 53.4 \\
\hline Phases of HBV infection & & & & \\
\hline
\end{tabular}




\begin{tabular}{|c|c|c|c|c|}
\hline Never infected $^{1}$ & 107 & 43.3 & 37.1 & 49.8 \\
\hline Immune due to natural infection ${ }^{2}$ & 81 & 32.8 & 27.0 & 39.0 \\
\hline Immune due to vaccination ${ }^{3}$ & 32 & 13.0 & 9.0 & 17.8 \\
\hline Acute infection $^{4}$ & 0 & 0.0 & & \\
\hline Acute resolving infection ${ }^{5}$ & 9 & 3.6 & 1.7 & 6.8 \\
\hline Chronic infection $^{6}$ & 18 & 7.3 & 4.3 & 11.3 \\
\hline \multicolumn{5}{|l|}{ Hepatitis serologic test of HCV } \\
\hline Anti $\mathrm{HCV}(+)$ & 0 & 0.0 & & \\
\hline $\begin{array}{r}{ }^{*} \text { se } \\
{ }^{1} \mathrm{HBsAg}(-) \text { anc } \\
{ }^{2} \mathrm{HBsAg}(-) \text { and } \\
{ }^{3} \mathrm{HBsAg}(-) \text { and } \\
{ }^{4} \mathrm{HBsAg}(+) \text { and anti-HBc(} \\
{ }^{5} \mathrm{HBsAg}(-) \text { and } \\
{ }^{6} \mathrm{HBsAg}(+) \text { and anti-HBc(}\end{array}$ & $\begin{array}{l}\text { i-HB } \\
\text { i-HB } \\
i-H B s \\
(+) a \\
\text { ti-HB } \\
(-) \text { ar }\end{array}$ & $\begin{array}{l}\mathrm{BBs}(-) \\
\mathrm{Bs}(-)\end{array}$ & & \\
\hline
\end{tabular}

\section{Knowledge, perception and practice among beauticians}

Of the 247 participants, one-third $(72 / 247,29.2 \%)$ had a low level of knowledge of hepatitis transmission and prevention; while, 110/247 (44.5\%) had moderate knowledge (Table S2). Additionally, $198 / 247$ (80.2\%) of the participants perceived an occupational risk for HBV and HCV infections in their profession. For knowledge on transmission, most participants 208/247 (84.2\%) were aware that HBV and HCV could be transmitted via blood transfusion, followed by sharing of instruments 196/247 (79.4\%), mother to infant perinatally $177 / 247$ (71.7\%), and sexual intercourse 158/247 (64.0\%). A majority of participants had good knowledge about preventing virus infection through avoiding contact with blood 230/247 (93.1\%), not sharing personal items $227 / 247$ (91.9\%), and getting HBV vaccination 225/247 (91.1\%). However, participants also had misconceptions about HBV and HCV transmission, reporting that they can be spread through eating 170/247 (68.8\%), cough 157/247 (63.6\%), insect bites 144/247 (58.3\%), talking 103/247 (41.7\%), and hugging 64/247 (25.9\%). Over 70\% (182/247) of participants had known that $\mathrm{HBV}$ vaccination is available, two-thirds (160/247, 64.8\%) knew that infections with HBV and HCV lead to liver cancer; and 197/247 (79.8\%) knew that yellow skin is a symptom of hepatitis.

Nearly half of the participants (113/247; 45.8\%) was categorized in the practicing prevention measures at a moderate level; meanwhile, around one-fifth (52/247; $21.0 \%$ ) practiced a low level (Table S3). Most participants $(198 / 247 ; 80.2 \%)$ had experienced injuries with blade or scissor-cuts during working, and a quarter (51/198; $25.8 \%$ ) had sustained injuries at least monthly. When injured, participants preferred alcohol for cleaning wounds (143/198; 72.2\%). Regarding hygienic practices, most participants $(14 / 16 ; 87.6 \%)$ reported washing their hands before and after providing tattooing services. However, over a half of participants reported washing their hands before haircutting and shaving (113/220;51.4\%), nail care (96/178; $53.9 \%)$ and around four fifths reported washing their hands after these procedures (79.5\% and $86.0 \%$, respectively). Soap or hand-washing liquid was frequently used for hand washing 185/247 (74.9\%). Disposable gloves were seldom available to participants $66 / 247$ (26.7\%), and only $19 / 66$ (7.7\%) reported wearing gloves while working. Additionally, a small number of participants $(9 / 246 ; 3.7 \%)$ sometimes reused blades or razors and one-fifth (58/230; 25.2\%) occasionally reused towels without washing. In regard to cleaning practices, $152 / 175$ (86.9\%) of respondents reported daily cleaning of manicuring and pedicuring clippers, $27 / 54$ (50\%) of hair clippers, 109/228 (47.8\%) of scissors and $102 / 236$ (43.2\%) of combs. Over two fifths (106/247; 42.9\%) of participants cleaned equipment after individual customers; whereas 96/247 (33.9\%) usually did so after a full working day. Equipment was most often cleaned by an antiseptic solution or soap (197/247, 79.8\%).

\section{The association between knowledge, perception, practice and $\mathrm{HBV}$ infection}

The study found no statistically significant association between knowledge, perception and practice of participants and HBV infection (Table 2). HBV prevalence among the low level of knowledge group was $4.2 \%$ compared to $7.3 \%$ in the moderate group and $10.8 \%$ among the high group. Regarding perception, an HBV prevalence of $5.6 \%$ was observed among participants who perceived occupational risks, while an HBV prevalence of $14.3 \%$ was observed among participants who did not perceive risks. The good overall preventive practice group showed lower HBV prevalence than the moderate or low-level group (6.1\% vs. $7.1 \%$ and $6.1 \%$ vs. 9.6\%). Bivariate analysis and logistic regression between other specific variables and $\mathrm{HBV}$ infection were also not statistically significant (data not shown). 
In addition, the HBV prevalence was not statistically significant different according to baseline characteristics of participants (data not shown). In particular, tattooing was not significantly linked to HBV infection, compared to other activities such as haircutting and shaving, manicuring and pedicuring.

Table 2. The relationship between knowledge, perception, practice and hepatitis B (HBV) infection among 247 beauticians in Quy Nhon City, Binh Dinh province, Viet Nam, 2017

\begin{tabular}{|c|c|c|c|c|c|c|c|}
\hline \multirow[t]{2}{*}{ Characteristics } & \multirow[t]{2}{*}{ Total } & \multicolumn{2}{|c|}{ HBsAg positive } & & \multicolumn{2}{|c|}{$95 \% \mathrm{Cl}$ for OR } & \multirow[t]{2}{*}{ p-value } \\
\hline & & Number & Percent & & Lower & Upper & \\
\hline Overall knowledge & & & & & & & $0.332^{b}$ \\
\hline Low & 72 & 3 & 4.2 & ref & & & \\
\hline Moderate & 110 & 8 & 7.3 & 1.80 & 0.46 & 7.04 & \\
\hline High & 65 & 7 & 10.8 & 2.78 & 0.69 & 11.22 & \\
\hline \multicolumn{4}{|c|}{ Perceived on occupation risks of HBV/HCV infection } & & & & $0.059^{a}$ \\
\hline No risk & 49 & 7 & 14.3 & 2.83 & 0.87 & 8.52 & \\
\hline Risk & 198 & 11 & 5.6 & ref & & & \\
\hline Overall preventive practice & & & & & & & $0.742^{\mathrm{b}}$ \\
\hline Good & 82 & 5 & 6.1 & ref & & & \\
\hline Moderate & 113 & 8 & 7.1 & 1.17 & 0.37 & 3.73 & \\
\hline Poor & 52 & 5 & 9.6 & 1.64 & 0.45 & 5.96 & \\
\hline${ }^{a}$ Fisher exact test & \multicolumn{6}{|c|}{${ }^{b}$ Chi-square test } & \\
\hline
\end{tabular}

\section{Discussion}

Beauticians working on beauty treatment activities are at risk for accidental injury with sharp equipment and at risk of contact clients' blood and body fluids. Beauticians may be an at-risk group for blood-borne virus infections especially by HIV, HBV and HCV. Several studies reported that beauty treatment activities, especially shaving and tattooing, might be associated with HBV and HCV infections. ${ }^{5-7,23-25}$ Our study demonstrated that the prevalence of HBV infection among beauticians in Quy Nhon City, Binh Dinh province was 7.3\% (95\% Cl: 4.4-11.3). This result was similar to the reported global HBV prevalence, indicating that Viet Nam was classified as a region of high-intermediate level of HBV infection (5-8\%). ${ }^{26}$ The prevalence in the study population was comparable to the HBV prevalence previously reported among the general population of Binh Dinh Province during 1998-2000 (10.6\%), ${ }^{27}$ Thai Nguyen province $(8.8 \%)^{12}$ and Quang Tri province (11.4\%). ${ }^{15}$ Nevertheless, the HBV prevalence from our study was lower than that the previous report among the general population in Thanh Hoa province (18.8\%), ${ }^{14}$ Thai Binh province (19.0\%), ${ }^{17}$ and Binh Thuan province (15.3\%). ${ }^{13}$ The lower prevalence rate observed in our study might be explained by the following reasons. Our participants were in an urban area, and most of them were in the young age group with relatively high educational level, implying that they could easily access health information and had higher health literacy, and conveniently receive medical services. Additionally, our study found that $13 \%$ of participants had been vaccinated against HBV; vaccination coverage percentages were not included in the cited studies.
Comparing HBV prevalence among beauticians in our study with studies among beauticians in other countries, our study population had a higher HBV prevalence than that from studies in Iran (1.1\%), ${ }^{25}$ Morocco (1.9\%), ${ }^{28}$ Turkey $(2.2 \%),{ }^{29}$ and Brazil $(0 \%),{ }^{10}$ but a lower prevalence than that from Ghana (14.5\%). ${ }^{30}$ Different HBV prevalence rates between countries could be due to differences in underlying HBV rates in the different population. ${ }^{26}$

The result of HBV genotyping from $18 \mathrm{HBsAg}(+)$ participants showed that $13 / 18$ (72.2\%) were infected with HBV genotype $\mathrm{B}$. The genotype of the remaining samples could not be identified, which could be due to low circulating viral copy numbers. ${ }^{31}$ Our result was similar to previous studies conducted in Vietnam that indicated that HBV genotype $B$ was the most prevalent $(63.0 \%-72.6 \%)$ followed by genotype $\mathrm{C}(18.0 \%-28.0 \%) \cdot{ }^{32-35}$

Like other studies, ${ }^{5,6,23,24,28,36}$ our results also showed no statistically significant association between possible occupational risk factors for HBV infection among beauticians. However, some studies have suggested that beauticians are a high-risk group for HBV and HCV infections based on the statistically significant difference in prevalence among case and control groups, ${ }^{24,36,37}$ or by comparing HBV infected cases with HAV infected cases as a control group. ${ }^{6}$ A systematic review and meta-analysis found that tattooing was a risk factor for HCV transmission in particular, but only in a non-professional setting..$^{23}$ Environmental contamination of HBV DNA on used razors was detected in one study, suggesting that transmission through the reuse of sharp grooming tools is possible. ${ }^{5}$ 
Our results also revealed that $45.8 \%$ (113/247) of participants had immunity against $\mathrm{HBV}$, resulting from vaccination $(13 \%, 32 / 247)$ or natural infection $(32.8 \%$, $81 / 247)$. In Vietnam, the hepatitis B vaccine program was formally introduced in 2003 and applied to all infants. ${ }^{16}$ We tried to exclude vaccinated persons from the study by only selecting individuals who were 18 years old or older. Nevertheless, some of the participants showed evidence of immunity from vaccination, implying that they likely purchased accessible vaccine. However, over $40.0 \%$ of beauticians were immunologically naïve to HBV, implying that they were still susceptible to the infection if exposed without taking preventive measures.

Regarding HCV, the prevalence rate of HCV infection among beauticians in the study was $0 \%$. This HCV prevalence was different from other studies among beauticians in Ghana $(0.5 \%),{ }^{30}$ Brazil $(0.8 \%),{ }^{10}$ Izmir, Turkey $(0.9 \%),{ }^{29}$ Morocco $(1.7 \%),{ }^{28}$ Teheran, Iran (2.0\%), ${ }^{25}$ Sivas, Turkey $(2.8 \%),{ }^{37}$ and Pakistan (6.97\%). ${ }^{38}$ We may not have had a sufficient sample size to detect HCV infection in a low prevalence population, and we calculated our sample size based on estimating HBV prevalence, not HCV prevalence.

\section{Limitations}

Information bias might have occurred during the interviewing process. Lack of information on sexual orientation could be another limitation. Recruitment bias could have occurred, because some beauty shops may have been on smaller streets and therefore unidentified by local health workers. In addition, some beauticians may have refused to visit PMC because of lack of available transportation, potential loss of income, or inability to leave work. However, this bias was minimized by providing flexible times outside of normal working hours for participants to attend PMC.

Further studies should include a control group for comparison analysis. In addition, using an alternative definition enabling recruitment of previously HBV infected subjects and excluding vaccinated persons might be more meaningful for analysis.

\section{Conclusions}

In conclusion, the prevalence of HBV and HCV infections among beauticians working in Quy Nhon city, Binh Dinh province was 7.3 and $0 \%$, respectively. The prevalence was comparable to previous studies and no occupational risk factors were linked with hepatitis B virus infection. Therefore, beauticians in Quy Nhon city may be not a highrisk group for HBV and HCV infections. However, the large proportion of participants without immunity (43.3\%) to HBV should be prioritized for vaccination. The percentage of beautican naïve to $\mathrm{HBV}$ infection can reflect the same picture in whole community, thus strategic promotions to encourage people for accessibility to vaccine should be implemented. Additionally, occupational training courses should be provided for beauticians to better understand how to protect themselves and their clients from HBV and HCV.

\section{Conflict of Interest: None}

\section{References}

1. WHO. Global Hepatitis Report. Geneva, Switzerland: World Health Organization, 2017.

2. WHO. Guidelines For The Prevention, Care And Treatment Of Persons With Chronic Hepatitis B Infection. Geneva, Switzerland: World Health Organization; 2015.

3. InternatioNAILS: Booming Business in Vietnam. Nails Magazine. Dec 2016:115.

4. Sun DX, Zhang FG, et al. Hepatitis $C$ transmission by cosmetic tattooing in women. Lancet (London, England) 1996; 347(9000): 541.

5. Cafer E, Muammer Z, et al. Detection of Hepatitis B Virus in Used Razor Blades by PCR. Hepatitis monthly 2010; 10(1): 22-5.

6. Mariano A, Mele A, et al. Role of beauty treatment in the spread of parenterally transmitted hepatitis viruses in Italy. Journal of medical virology 2004; 74(2): 216-20.

7. Amodio E, Di Benedetto MA, et al. Knowledge, attitudes and risk of HIV, HBV and HCV infections in hairdressers of Palermo city (South Italy). European journal of public health 2010; 20(4): 433-7.

8. Koroglu M, Demiray T, et al. Nail scissors and fingernails as reservoirs of hepatitis $B$ virus DNA: Role of nail scissors in household transmission of hepatitis $B$ virus. American Journal of Infection Control 2018.

9. S. Shalaby, I.A. Kabbash, et al. Hepatitis B and $C$ viral infection prevalence knowledge, attitude and practice among barbers and clients in Gharbia governorate, Egypt. Eastern Mediterranean Health Journal 2010; 16(1): 10-7.

10. Villar LM, de Paula VS, et al. Knowledge and prevalence of viral hepatitis among beauticians. Journal of medical virology 2014; 86(9): 1515-21.

11. Yang J, Hall K, et al. Risk for hepatitis B and C virus transmission in nail salons and barbershops and state regulatory requirements to prevent such transmission in the United States. Journal of public health management and practice : JPHMP 2014; 20(6): E20-30.

12. Duong $\mathrm{TH}, \mathrm{Nguyen} \mathrm{PH}$, et al. Risk factors for hepatitis $B$ infection in rural Vietnam. Asian Pacific journal of cancer prevention : APJCP 2009; 10(1): 97-102.

13. Do SH, Yamada H, et al. High prevalences of hepatitis $B$ and $C$ virus infections among adults living in Binh Thuan province, Vietnam. Hepatology research : the official journal of the Japan Society of Hepatology 2015; 45(3): 259-68.

14. Hipgrave DB, Nguyen TV, et al. Hepatitis B infection in rural Vietnam and the implications for a national 
program of infant immunization. Am J Trop Med Hyg 2003; 69(3): 288-94.

15. Viet L, Lan NTN, et al. Prevalence of hepatitis B \& hepatitis $C$ virus infections in potential blood donors in rural Vietnam. The Indian Journal of Medical Research 2012; 136(1): 74-81.

16. Nguyen VT. Hepatitis B infection in Vietnam: current issues and future challenges. Asia-Pacific journal of public health 2012; 24(2): 361-73.

17. Nguyen VT, McLaws M-L, et al. Prevalence and risk factors for hepatitis $C$ infection in rural north Vietnam. Hepatology International 2007; 1(3): 387-93.

18. Kallman JB, Tran S, et al. Vietnamese community screening for hepatitis $B$ virus and hepatitis $C$ virus. Journal of viral hepatitis 2011; 18(1): 70-6.

19. Sereno L, Mesquita F, et al. Epidemiology, responses, and way forward: the silent epidemic of viral hepatitis and HIV coinfection in Vietnam. Journal of the International Association of Physicians in AIDS Care (Chicago, III : 2002) 2012; 11(5): 311-20.

20. WHO. Hepatitis B. n.d. http://www.wpro.who.int/ vietnam/topics/hepatitis/factsheet/en/ (accessed 05/04 2017).

21. WHO. Hepatitis C. n.d. http://www.wpro.who.int/ vietnam/topics/hepatitis/factsheet_hepc/en/ (accessed 05/04 2017).

22. Daniel WW, \& Cross, C. L. . Biostatistics: A foundation for analysis in the health sciences (10th ed.): John Wiley\&Sons; 2014

23. Jafari S, Copes $\mathrm{R}$, et al. Tattooing and the risk of transmission of hepatitis $\mathrm{C}$ : a systematic review and meta-analysis. International Journal of Infectious Diseases 2010; 14(11): e928-40.

24. Carney K, Dhalla S, et al. Association of tattooing and hepatitis $C$ virus infection: a multicenter case-control study. Hepatology 2013; 57(6): 2117-23.

25. Khairkhah T, Shamsa A, et al. Analysis of Knowledge, Attitudes, and Prevalence of Hepatitis B and C Seromarkers Among Barbers in Tehran. Hepatitis monthly 2016; 16(9): e39416.

26. Ott JJ, Stevens GA, et al. Global epidemiology of hepatitis $B$ virus infection: new estimates of age-specific HBsAg seroprevalence and endemicity. Vaccine 2012; 30(12): 2212-9.

27. Institute of Public Health. Health status of HBV carrier in Binh Dinh province (unpublished report). Ho Chi Minh city, Vietnam; 2015.

28. Belbacha I, Cherkaoui I, et al. Seroprevalence of hepatitis $B$ and $C$ among barbers and their clients in the Rabat region of Morocco. Eastern Mediterranean health journal = La revue de sante de la Mediterranee orientale = al-Majallah al-sihhiyah li-sharq al-mutawassit 2011; 17(12): 911-9.

29. Kose S, Mandiracioglu A, et al. Seroprevalence of hepatitis $B$ and $C$ viruses: Awareness and safe practices of hairdressers in Izmir - A survey. International Journal of Occupational Medicine and Environmental Health 2011; 24(3).

30. Adoba P, Boadu SK, et al. High prevalence of hepatitis B and poor knowledge on hepatitis $B$ and $C$ viral infections among barbers: a cross-sectional study of the Obuasi municipality, Ghana. BMC public health 2015; 15: 1041.

31. European Association for the Study of the Liver EASL 2017 Clinical Practice Guidelines on the management of hepatitis B virus infection. Journal of hepatology 2017; 67(2): 370-98.

32. Bui TTT, Tran TT, et al. Molecular characterization of hepatitis B virus in Vietnam. BMC Infectious Diseases 2017; 17(1): 601.

33. Nguyen LH, Ha NB, et al. Prevalence of hepatitis B virus genotype $\mathrm{B}$ in Vietnamese patients with chronic hepatitis B. Hepatology International 2009; 3(3): 461-7.

34. Thuy le TT, Ryo $\mathrm{H}$, et al. Distribution of genotype/ subtype and mutational spectra of the surface gene of hepatitis B virus circulating in Hanoi, Vietnam. Journal of medical virology 2005; 76(2): 161-9.

35. Truong BX, Seo Y, et al. Genotype and variations in core promoter and pre-core regions are related to progression of disease in HBV-infected patients from Northern Vietnam. International journal of molecular medicine 2007; 19(2): 293-9.

36. Mele A, Corona R, et al. Beauty treatments and risk of parenterally transmitted hepatitis: results from the hepatitis surveillance system in Italy. Scandinavian journal of infectious diseases 1995; 27(5): 441-4.

37. Candan $\mathrm{F}$, Alagozlu $\mathrm{H}$, et al. Prevalence of hepatitis $B$ and $C$ virus infection in barbers in the Sivas region of Turkey. Occupational medicine (Oxford, England) 2002; 52(1): 31-4.

38. Abdul Majeed Akhtar, Sadia Majeed. Hepatitis C virus infection among barbers and beauticians in Lahore, an analytical cross sectional study. Scilnt(Lahore) 2015; 27(5): 4303-8.

Date of Submission: 2018-07-19 Date of Acceptance: 2018-07-27 
Table S1. Baseline characteristics of 247 beauticians in Quy Nhon City, Binh Dinh Province, Viet Nam, 2017

\begin{tabular}{|c|c|c|}
\hline Characteristics & Number & Percent \\
\hline \multicolumn{3}{|c|}{ Age group (years) } \\
\hline $18-<30$ & 133 & 53.9 \\
\hline $30-45$ & 90 & 36.4 \\
\hline$>45$ & 24 & 9.7 \\
\hline \multicolumn{3}{|c|}{ Mean \pm standard deviation (SD) of age (minimum - maximum): $30.8 \pm 10.2(18-67)$} \\
\hline \multicolumn{3}{|c|}{ Gender } \\
\hline Male & 47 & 19.0 \\
\hline Female & 200 & 81.0 \\
\hline \multicolumn{3}{|c|}{ Ethnicity } \\
\hline Viet (Kinh) & 247 & 100.0 \\
\hline \multicolumn{3}{|c|}{ Religion } \\
\hline Buddhist & 78 & 31.6 \\
\hline Christian & 25 & 10.1 \\
\hline Non-religious and others & 146 & 59.1 \\
\hline \multicolumn{3}{|l|}{ Marital status } \\
\hline Married & 146 & 59.1 \\
\hline Single & 94 & 38.1 \\
\hline Divorced & 7 & 2.8 \\
\hline \multicolumn{3}{|c|}{ Highest level of education attained } \\
\hline Illiterate or primary & 20 & 8.1 \\
\hline Secondary & 111 & 44.9 \\
\hline High school and more & 116 & 47.0 \\
\hline \multicolumn{3}{|c|}{ Monthly income } \\
\hline$\leq \$ 100$ & 54 & 21.9 \\
\hline$\$ 101-249$ & 107 & 43.3 \\
\hline$\geq \$ 250$ & 86 & 34.8 \\
\hline \multicolumn{3}{|c|}{ Mean \pm SD of $\$$ income (minimum - maximum): $200 \pm 130(50-1000)$} \\
\hline \multicolumn{3}{|c|}{ Median (Interquartile range [IQR]) of \$ income: $150(120)$} \\
\hline \multicolumn{3}{|c|}{ Years of working experience } \\
\hline$<5$ years & 114 & 46.2 \\
\hline $5-9$ years & 41 & 16.6 \\
\hline$\geq 10$ years & 92 & 37.2 \\
\hline \multicolumn{3}{|c|}{ Mean \pm SD of years of working experience (minimum - maximum): $8.0 \pm 7.8(0.5-45)$} \\
\hline \multicolumn{3}{|c|}{ Median (IQR) of years of working experience: $5.0(8.0)$} \\
\hline \multicolumn{3}{|c|}{ Activities provided by beauticians } \\
\hline Haircut and shaving & 220 & 89.1 \\
\hline Washing hair & 208 & 84.2 \\
\hline Manicurist/pedicurist & 178 & 72.1 \\
\hline Squeezing spot & 105 & 42.5 \\
\hline Cleaning ear & 60 & 24.3 \\
\hline
\end{tabular}




\begin{tabular}{|c|c|c|}
\hline Tattoo & 16 & 6.5 \\
\hline \multicolumn{3}{|c|}{ Number of activities provided by individual beautician } \\
\hline $1-3$ & 146 & 59.1 \\
\hline $4-6$ & 101 & 40.9 \\
\hline \multicolumn{3}{|c|}{ Average of clients served each day } \\
\hline $1-4$ & 32 & 13.0 \\
\hline $5-9$ & 134 & 54.3 \\
\hline$\geq 10$ & 81 & 32.8 \\
\hline \multicolumn{3}{|c|}{ Mean \pm SD of average of clients per day (minimum - maximum): $7.8 \pm 3.8(1-23)$} \\
\hline History of blood transfusion ${ }^{1}$ & 7 & 2.8 \\
\hline History of tattoo ${ }^{2}$ & 39 & 15.8 \\
\hline \multicolumn{3}{|c|}{${ }^{1} 95 \% \mathrm{Cl}: 1.1 \%-5.7 \% \quad{ }^{2} 95 \% \mathrm{Cl}: 11.5 \%-20.9 \%$} \\
\hline
\end{tabular}

Table S2. Knowledge and perception on occupation risk for hepatitis B virus and hepatitis C virus (HBV/HCV) infections among 247 beauticians in Quy Nhon City, Binh Dinh Province, Viet Nam, 2017

\begin{tabular}{|c|c|c|}
\hline Knowledge and perception & Number & Percent \\
\hline \multicolumn{3}{|l|}{ Number of knowledge questions correctly answered } \\
\hline Low (<60\% questions correctly answered) & 72 & 29.2 \\
\hline Moderate (60-80\% questions correctly answered) & 110 & 44.5 \\
\hline Good (>80\% questions correct) & 65 & 26.3 \\
\hline \multicolumn{3}{|l|}{ Knowledge of HBV/HCV transmission modes } \\
\hline Blood transfusion ${ }^{1}$ & 208 & 84.2 \\
\hline Contaminated instruments $^{1}$ & 196 & 79.4 \\
\hline Hugging $^{2}$ & 183 & 74.1 \\
\hline Mother to child tranmission ${ }^{1}$ & 177 & 71.7 \\
\hline Sexual intercourse ${ }^{1}$ & 158 & 64.0 \\
\hline Talking ${ }^{2}$ & 144 & 58.3 \\
\hline Biting of insects ${ }^{2}$ & 103 & 41.7 \\
\hline Cough $^{2}$ & 90 & 36.4 \\
\hline \multicolumn{3}{|l|}{ Knowledge about preventive activities to HBV/HCV infections } \\
\hline Avoiding exposure to blood ${ }^{1}$ & 230 & 93.1 \\
\hline Avoiding sharing personal instruments ${ }^{1}$ & 227 & 91.9 \\
\hline Vaccination for preventing HBV infection ${ }^{1}$ & 225 & 91.1 \\
\hline No eating together with infected person ${ }^{2}$ & 77 & 31.2 \\
\hline \multicolumn{3}{|l|}{ Know the availability of vaccination } \\
\hline HBV vaccination $^{1}$ & 182 & 73.7 \\
\hline $\mathrm{HCV}_{\text {vaccination }}^{2}$ & 55 & 22.3 \\
\hline Know the probability of leading to liver cancer of $\mathrm{HBV} / \mathrm{HCV}^{1}$ & 160 & 64.8 \\
\hline \multicolumn{3}{|l|}{ Knowledge about signs and symptoms of HBV/HCV infections } \\
\hline Yellow skin ${ }^{1}$ & 197 & 79.8 \\
\hline Fatigue $^{1}$ & 147 & 59.5 \\
\hline Fever $^{1}$ & 112 & 45.3 \\
\hline Nausea, vomiting ${ }^{1}$ & 70 & 28.3 \\
\hline
\end{tabular}




\begin{tabular}{|c|c|c|}
\hline Cough $^{1}$ & 59 & 23.9 \\
\hline Diarrhea $^{1}$ & 47 & 19.0 \\
\hline Perceived occupational risks of HBV/HCV infections & & \\
\hline No risk & 49 & 19.8 \\
\hline Having risk & 198 & 80.2 \\
\hline Low risk & 90 & 36.4 \\
\hline Moderate risk & 75 & 30.4 \\
\hline High risk & 33 & 13.4 \\
\hline${ }^{1}$ Positive item (correct answer is yes) ${ }^{2}$ Negative item (correct answer is no) & & \\
\hline
\end{tabular}

Table S3. Preventive practices to hepatitis B virus and hepatitis $\mathrm{C}$ virus $(\mathrm{HBV} / \mathrm{HCV})$ infections among 247 beauticians in Quy Nhon City, Binh Dinh Province, Viet Nam, 2017

\begin{tabular}{|c|c|c|}
\hline Practice & Number & Percent \\
\hline \multicolumn{3}{|l|}{ Number of practice questions correctly answered } \\
\hline Low (<60\% questions correctly answered) & 52 & 21.0 \\
\hline Moderate (60-80\% questions correctly answered) & 113 & 45.8 \\
\hline Good (>80\% questions correct) & 82 & 33.2 \\
\hline \multicolumn{3}{|l|}{ Reported blade-cuts/scissor-cuts when working } \\
\hline No & 49 & 19.8 \\
\hline Yes & 198 & 80.2 \\
\hline One a week & 10 & 5.1 \\
\hline One a month & 41 & 20.7 \\
\hline One for every three months & 72 & 36.7 \\
\hline One for every six months & 37 & 18.7 \\
\hline One a year & 38 & 19.2 \\
\hline \multicolumn{3}{|l|}{ First aid practices $(n=198)$} \\
\hline Washing with alcohol & 143 & 72.2 \\
\hline Compressing by bandage/clothes & 35 & 17.7 \\
\hline Washing with water/water with soap & 12 & 6.1 \\
\hline Nothing & 8 & 4.0 \\
\hline \multicolumn{3}{|l|}{ Handwashing practices } \\
\hline Before haircut/shaving $(n=220)$ & 113 & 51.4 \\
\hline After haircut/shaving $(n=220)$ & 175 & 79.5 \\
\hline Before manicuring/pedicuring $(n=178)$ & 96 & 53.9 \\
\hline After manicuring/pedicuring ( $n=178)$ & 153 & 86.0 \\
\hline Before tattooing $(n=16)$ & 14 & 87.6 \\
\hline After tattooing $(\mathrm{n}=16)$ & 14 & 87.6 \\
\hline Hand washing with soap or hand-washing liquid & 185 & 74.9 \\
\hline Availability of disposable gloves at shop & 66 & 26.7 \\
\hline Wearing gloves when working & 19 & 7.7 \\
\hline Haircut or shaving $(n=220)$ & 4 & 1.8 \\
\hline Manicuring/pedicuring ( $n=178)$ & 4 & 2.3 \\
\hline Tattooing $(n=16)$ & 13 & 81.3 \\
\hline
\end{tabular}




\begin{tabular}{|c|c|c|}
\hline Changing new gloves for every single client $(n=19)$ & 17 & 89.5 \\
\hline Changing new razors/blades for each client $(n=246)$ & 237 & 25.2 \\
\hline Reusing towel without washing ( $n=230)$ & 58 & 47.8 \\
\hline Daily cleansing scissors ( $n=228)$ & 109 & 86.9 \\
\hline Daily cleansing clippers for manicuring/pedicuring ( $n=175)$ & 152 & 50.0 \\
\hline Daily cleansing hair clippers ( $n=54)$ & 27 & 43.2 \\
\hline Daily cleansing combs (n=236) & 102 & 42.9 \\
\hline Frequency of cleaning equipment & & 33.9 \\
\hline After every customer & 106 & 18.2 \\
\hline After a working day & 96 & \\
\hline When necessary & 45 & 79.8 \\
\hline Methods applied for cleansing instruments & & 6.9 \\
\hline Washing with soap/antiseptic & 197 & 4.1 \\
\hline Water & 17 & 9.3 \\
\hline Boiling & 10 & \\
\hline
\end{tabular}

